\title{
Remarks on Polygot Applications
}

\author{
I. Mary Linda, C. Anuradha, S. Pothumani
}

\begin{abstract}
Cloud Computing is one of the upcoming service. It has providing many services to users along with these services we introduced a new service called Testing as a Service (TAAS) it adds value to the services in Cloud. Generally, web application developers facing difficulties to test their own applications in local host. Because it necessary to check whether their application properly running in different environment it consumes more time and cost for requirements. In this paper We proposed an automatic testing in cloud in which the developers can test their own application in different environment using virtual computing machine in cloud in which selenium web driver can be used to drive the application in specified browser in specified environment. It is necessary for the user to store their test cases to test their application hence for users privacy we are providing client side encryption. Using BEEFISH. We are using a FLASK to create a web application for testing service.
\end{abstract}

\section{Keywords: POLYGOT, Web Application}

\section{INTRODUCTION}

Cloud computing means the practise of using an network of remote server hosted on the internet to store, manage, and process the data rather than a local server or personal computer .It provides a three types of services.

1. Software as a service

2. Platform as a service

3. Infrastructure as a service

Along with these services it leads an opportunity in offering testing as a service (TAAS) for SAAS. In this paper, we providetesting as a service, which is a new service model in which a providers undertakes software testing activities of a given web application system in a cloud infrastructure for customers as a service based on their demands. Testing an application across an internet supports a demand-led software testing market to provide and acquire testing whenever its needed, from anywhere around the globe [1-8].

This paper is written to achieve testing a web application in a different environment in Amazoncloud (different OS and browsers). This paper also focuses on the issues of testing web application on a local machine and cloud. It also covers the privacy of user's data. In addition, it covers how to automatically drive the web application to a machine.

\section{Testing in Cloud}

When we are testing our application in a cloud we take advantage of hardware and bandwidth and other resources.

Revised Manuscript Received on August 22, 2019.

I. Mary Linda, Department of CSE, Bharath Institute of Higher Education and Research, Chennai, Tamilnadu, India.

C. Anuradha Department of CSE, Bharath Institute of Higher Education and Research, Chennai, Tamilnadu, India.

S. Pothumani, Department of CSE, Bharath Institute of Higher Education and Research, Chennai, Tamilnadu, India
Since we are doing our testing in online we can able to do testing anywhere [9-14].

\section{A. Why cloud is needed for testing?}

- $\quad$ Reduce cost by using virtualized resources and shared cloud infrastructure to eliminate required computer resources and licensed software costs.

\section{- $\quad$ On-demand test services to conduct large-scale and} effective real-time online validation for internet based software in clouds [15-18].

\section{B. Issues In Testing Web Application On a Local Machine And Cloud}

- Web application testing on a local host can be carried out as an engineering task with in in-house whereas; in cloud we provide a real time online testing on-demand.

- In local host testing cannot be done online, using cloud testing can be done globally by both public cloud.

- Testing cost will be more since it requires an additional hardware and software (license) on a local host whereas we can use resources directly from cloud.

- Testing environment is pre-fixed and configured. In cloud it is an open public environment [19-22].

\section{EXISTING METHOD}

Previously, while testing our application it is necessary test whether its running in all the environment and server is producing a result properly since different users using a different operating system and browsers. Hence, testing was performed manually this consumed lot of time and difficulties to focus on testing for every individuals web applications. While using local host we need to have all the necessary resources like software and hardware and it was pre-fixed [23-26].

\section{RESULTS AND DISCUSSION}

In this paper we proposed a new service that is we can test our web application in a different environment remotely in cloud. FLASK is used as a python micro framework for web application. The user can upload their test cases of theirapplication and select their environment to test their web app. for users privacy we are providing an encryption at client side using BEEFISH. The report for the testing will be send as an html; the user can receive report to their mail which they have specified. This is achieved using Amazon web services. Amazon EC2 is used as virtual server for computation. 


\section{A. Architecture}

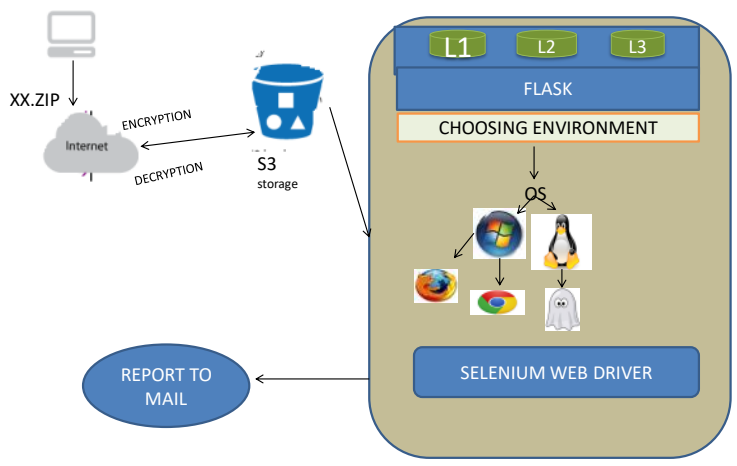

L1,L2,L3 - Instances(virtual computing environment).

\section{B. Client Side Encryption}

- Amazon cloud provides a many services to users in this storage is one of it we are using Amazon S3 to storing a data even it provides a server side encryption it is necessary to provide an encryption on client side for users privacy. For client side encryption we are using BEEFISH which in turns a pycryto. Pycryto is an encryption algorithm written in python using AES algorithm. Python is an open source language hence it is more flexible to use. Here we use BOTO library which is a python API for connecting with AWS.This can be done in two ways.

-i. Without password

- ii. With password

- If we are not providing any password in client side, the server will return the original data without asking password. In second case, the server will return the original data only by providing a correct password which was given in client side [27].

\section{Creating Different Environment}

Amazon EC2 eliminates needs to invest in hardware and software (license). It can be used to launch as many or as few virtual server as per the requirement. One of thefeatures of EC2 isAmazon Machine Image (AMI) which provides information required to launch an instance, which is a virtual server in the cloud. We need to specify AMI when we launch instance and we can launch many instance from AMI. Instance means virtual computing environment. Hence we can create different environment using AMI.

AMI has a template for the root volume for the instance including operating system and additional software. In our service we used windows and Linux as a different environment. The browsers for windows are Firefox, chrome and for Linux is headlessbrowser, other browsers also can be configured using instances [28-30].

Here we arerunning our web application on different OS and different browsers. The testing can be done based on test case criteria. For automating the web browsers for testing we are using selenium web driver which is used to driving the browser natively as a user would locally or on a remote machine.

\section{Generation of Report}

The report will be generated based on test cases. If all the criteria of test case are satisfied during testing the application passed the test else failed. The report will be generated in the form of HTML. The server will mail the report to user which is specified.

\section{CONCLUSION}

This service reduces the burden of user of testing their application in different environment it requires all necessary resources, time and user effort. As we see before it is easy to test their application in different environment by using this service. It alsoreduces cost and time. Even this service is more efficient and time consistent it can be improve furtherby testing the application simultaneously in different browsers and different OS.

\section{REFERENCES}

[1] Gowri Sankaran, B., Karthik, B. \& Vijayaragavan, S.P. 2019, "Weight ward change region plummeting change for square based image huffman coding", International Journal of Innovative Technology and Exploring Engineering, vol. 8, no. 10, pp. 4313-4316.

[2] Gowri Sankaran, B., Karthik, B. \& Vijayaragavan, S.P. 2019, "Image compression utilizing wavelet transform", International Journal of Innovative Technology and Exploring Engineering, vol. 8, no. 10, pp. 4305-4308.

[3] Kandavel, N. \& Kumaravel, A. 2019, "Offloading computation for efficient energy in mobile cloud computing", International Journal of Innovative Technology and Exploring Engineering, vol. 8, no. 10, pp. 4317-4320.

[4] Vinoth, V.V. \& Kanniga, E. 2019, "Reversible data hiding in encrypting images-an system", International Journal of Engineering and Advanced Technology, vol. 8, no. 6, pp. 3051-3053.

[5] Selvapriya, B. \& Raghu, B. 2019, "Pseudocoloring of medical images: A research", International Journal of Engineering and Advanced Technology, vol. 8, no. 6, pp. 3712-3716.

[6] Senthil Kumar, K. \& Muthukumaravel, A. 2019, "Bi-objective constraint and hybrid optimizer for the test case prioritization", International Journal of Engineering and Advanced Technology, vol. 8, no. 6 , pp. $3436-3448$.

[7] Kavitha, G., Priya, N., Anuradha, C. \& Pothumani, S. 2019, "Read-write, peer-to-peer algorithms for the location-identity split", International Journal of Innovative Technology and Exploring Engineering, vol. 8, no. 9 Special Issue 3, pp. 445-447.

[8] Kaliyamurthie, K.P., Michael, G., Anuratha, C. \& Sundaraj, B. 2019, "Certain improvements in alzheimer disease classification using novel fuzzy c means clustering for image segmentation", International Journal of Innovative Technology and Exploring Engineering, vol. 8, no. 9 Special Issue 3, pp. 599-604.

[9] Kaliyamurthie, K.P., Sundarraj, B., Geo, A.V.A. \& Michael, G. 2019 , "RIB: Analysis of I/O automata", International Journal of Innovative Technology and Exploring Engineering, vol. 8, no. 9 Special Issue 3, pp. 1019-1022.

[10] Velvizhi, R., Rajabhushanam, C. \& Vidhya, S.R.S. 2019, "Opinion mining for travel route recommendation using Social Media Networks (Twitter)", International Journal of Innovative Technology and Exploring Engineering, vol. 8, no. 9 Special Issue 3, pp. 508-512.

[11] Kavitha, R., Sangeetha, S. \& Varghese, A.G. 2019, "Human activity patterns in big data for healthcare applications", International Journal of Innovative Technology and Exploring Engineering, vol. 8, no. 9 Special Issue 3, pp. 1101-1103.

[12] Pothumani, S., Anandam, A.K., Sharma, N. \& Franklin, S. 2019, "Extended VEOT framework - Implemented in a smart boutique", International Journal of Innovative Technology and Exploring Engineering, vol. 8, no. 9 Special Issue 3, pp. 762-767.

[13] Kaliyamurthie, K.P., Michael, G., Krishnan, R.M.V. \& 
Sundarraj, B. 2019, "Pseudorandom techniques for the internet", International Journal of Innovative Technology and Exploring Engineering, vol. 8, no. 9 Special Issue 3, pp. 915-918.

[14] Aravindasamy, R., Jeffrin Rajan, M., Rama, A. \& Kavitha, P. 2019 "Deep learning provisions in the matlab: Focus on CNN facility", International Journal of Innovative Technology and Exploring Engineering, vol. 8, no. 9 Special Issue 3, pp. 990-994.

[15] Theivasigamani, S., Linda, M. \& Amudha, S. 2019, "Object sensing and its identification \& motion sensing", International Journal of Innovative Technology and Exploring Engineering, vol. 8, no. 9 Special Issue 3, pp. 545-549.

[16] Mary Linda, I., Vimala, D. \& Shanmuga Priya, K. 2019, "A methodology for the emulation of IPv4", International Journal of Innovative Technology and Exploring Engineering, vol. 8, no. 9 Special Issue 3, pp. 848-852.

[17] Velvizhi, R., Priya, D.J., Vimala, D. \& Linda, I.M. 2019, "Increased routing algorithm for mobile adhoc networks", International Journal of Innovative Technology and Exploring Engineering, vol. 8, no. 9 Special Issue 3, pp. 1606-1608

[18] Sangeetha, S., Anuradha, C. \& Priya, N. 2019, "DNS in real world", International Journal of Innovative Technology and Exploring Engineering, vol. 8, no. 9 Special Issue 3, pp. 937-940.

[19] Geetha, C., Vimala, D. \& Priya, K.S. 2019, "Constructing multi-processors and spreadsheets with SKIVE", International Journal of Innovative Technology and Exploring Engineering, vol. 8, no. 9 Special Issue 3, pp. 516-519.

[20] Yugendhar, K., Sugumar, V. \& Kavitha, P. 2019, "A novel method of univac using fuzzy logic", International Journal of Innovative Technology and Exploring Engineering, vol. 8, no. 9 Special Issue 3, pp. 435-437.

[21] Kaliyamurthie, K.P., Michael, G., Elankavi, R. \& Jijo, S.A. 2019, "Implementing aggregate-key for sharing data in cloud environment using cryptographic encryption", International Journal of Innovative Technology and Exploring Engineering, vol. 8, no. 9 Special Issue 3, pp. 957-959.

[22] Jeffrin Rajan, M., Aravindasamy, R., Kavitha, P. \& Rama, A. 2019, "A novel method of object orientation variation in $\mathrm{C}++$ and java", International Journal of Innovative Technology and Exploring Engineering, vol. 8, no. 9 Special Issue 3, pp. 708-710.

[23] Nayak, R., Dinesh, S. \& Thirunavukkarasu, S. 2019, "A novel method improvement of rapid miner for the data mining applications", International Journal of Innovative Technology and Exploring Engineering, vol. 8, no. 9 Special Issue 3, pp. 457-460.

[24] Sivaraman, K., Krishnan, R.M.V., Sundarraj, B. \& Sri Gowthem, S. 2019, "Network failure detection and diagnosis by analyzing syslog and SNS data: Applying big data analysis to network operations", International Journal of Innovative Technology and Exploring Engineering, vol. 8, no. 9 Special Issue 3, pp. 883-887.

[25] Vimala, D., Linda, I.M. \& Priya, K.S. 2019, "Decoupling online algorithms from erasure coding in DNS", International Journal of Innovative Technology and Exploring Engineering, vol. 8, no. 9 Special Issue 3, pp. 950-953.

[26] Rama, A., Kumaravel, A. \& Nalini, C. 2019, "Preprocessing medical images for classification using deep learning techniques", International Journal of Innovative Technology and Exploring Engineering, vol. 8, no. 9 Special Issue 3, pp. 711-716.

[27] Sangeetha, S., Srividhya, S.R., Anita Davamani, K. \& Amudha, S 2019, "A procedure for avoid overrun error in universal synchronous asynchronous receiver transmitter (usart) by utilizing dummy join and interrupt latency method", International Journal of Innovative Technology and Exploring Engineering, vol. 8, no. 9 Special Issue 3, pp. 657-660.

[28] Aravindasamy, R., Jeyapriya, D., Sundarajan, B. \& Sangeetha, S. 2019, "Data duplication in cloud for optimal performance and security", International Journal of Innovative Technology and Exploring Engineering, vol. 8, no. 9 Special Issue 3, pp. 1156-1158.

[29] Aravindasamy, R., Jeffrin Rajan, M., Sugumar, V. \& Kavitha, P. 2019, "A novel method on developing superblocks and the transistor using apodryal", International Journal of Innovative Technology and Exploring Engineering, vol. 8, no. 9 Special Issue 3, pp. 982-985.

[30] Sasikumar, C.S. \& Kumaravel, A. 2019, "E-learning attributes selection through rough set theory and data mining", International Journal of Innovative Technology and Exploring Engineering, vol. 8, no. 10 , pp. $3920-3924$

\section{AUTHORS PROFILE}

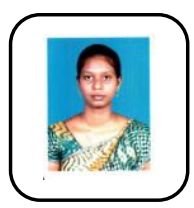

I. Mary Linda, Assistant Professor, Department of Computer Science \& Engineering, Bharath Institute of Higher Education and Research, Chennai, India

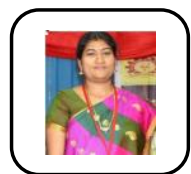

C. Anuradha Assistant Professor, Department of Computer Science \& Engineering, Bharath Institute of Higher Education and Research, Chennai, India

S. Pothumani, Assistant Professor, Department of Computer Science \& Engineering, Bharath Institute of Higher Education and Research, Chennai, India 